\title{
In virga Aaron Maria ostendebatur. Nueva interpretación del ramo de lirios en $L a$ Anunciación gótica española a la luz de fuentes patrísticas y teológicas
}

\author{
José María SALvador GonzÁLEZ \\ Universidad Complutense de Madrid \\ Departamento de Historia del Arte I (Medieval) \\ jmsalvad@ucm.es
}

Recibido: 20-02-2014

Aceptado: 02-09-2014

\section{RESUMEN}

En abierto desacuerdo con la convencional interpretación del lirio en el tema iconográfico de La Anunciación -ilustrado con gran pertinencia en las diez pinturas góticas españolas que aquí analizamos-, el presente artículo $^{1}$ propone dos nuevas explicaciones teológicas de dicha flor en esa escena bíblica. Nos basamos para ello en numerosas y concordantes exégesis de prestigiosos Padres de la Iglesia y teólogos medievales sobre el prodigioso florecimiento de la vara seca de Aarón. Así, fundándonos en esa perfecta coincidencia exegética de los pensadores cristianos, la cual certifica en ese punto una consolidada tradición dogmática a lo largo de casi un milenio, tratamos de mostrar que el ramo de lirios en la escena de la Anunciación exhibe dos profundos simbolismos, cristológico y mariológico, interrelacionados de manera esencial, a saber: ese ramo de lirios significa al mismo tiempo la sobrenatural encarnación humana de Dios Hijo y la virginal maternidad divina de María.

Palabras clave: Arte medieval, iconografía, pintura gótica española, mariología, cristología, patrística, teología.

\section{In virga Aaron Maria ostendebatur. New interpretation of the bouquet of lilies in the spanish gothic Annunciation in the light of patristic and theological sources}

\begin{abstract}
In clear disagreement with the conventional interpretation of the lily in the iconographic theme of The Annunciation -illustrated with great approprieteness in the ten Spanish Gothic paintings we discussed here-, this paper proposes two new theological explanations of such flower in this biblical scene. We

1 Este artículo es producto de la actividad investigadora que el autor desarrolla como Director del Grupo de Investigación CAPIRE, adscrito al Departamento de Historia del Arte I (Medieval) en la Universidad Complutense de Madrid, y como miembro del Grupo de Investigación del CNPq del Brasil "Arte, Filosofia e Literatura na Idade Média", coordinado por el Dr. Ricardo da Costa, Profesor efectivo (Asociado III) del Departamento de Teoría del Arte y la Música en la Universidade Federal do Espírito Santo (UFES), Vitória, Brasil.
\end{abstract}


rely for this on numerous and consistent exegesis of prestigious Church Fathers and medieval theologians on the prodigious flowering of dry rod of Aaron. Thus, basing ourselves in that perfect exegetical matching of Christian thinkers, which certifies in this issue an established dogmatic tradition over nearly a millennium, we try to show that the bouquet of lilies in the Annunciation scene shows two deep symbolisms, Christological and Mariological, essentially interrelated, i.e.: that bouquet of lilies means both the supernatural human incarnation of God the Son and Mary's virginal motherhood of God.

Key words: Medieval art, iconography, Spanish Gothic painting, Mariology, Christology, Patristics, theology.

\section{Proemio, a modo de recordatorio}

En nuestra primera aproximación hermenéutica al motivo del ramo de lirios en las imágenes góticas de La Anunciación, ${ }^{2}$ inferimos algunas conclusiones de importancia, que resulta útil rememorar ahora, antes de iniciar nuestra segunda interpretación iconográfica sobre el tema.

Se puso de relieve en aquel primer trabajo que, en lo esencial, las representaciones de La Anunciación se inspiran de manera directa y explícita en el Evangelio de San Lucas, sin interferencias de los escritos apócrifos, ni tan siquiera de La Leyenda Dorada de Santiago de la Vorágine. ${ }^{3}$

Se indicó asimismo que, tras largas centurias de desarrollo en fórmulas de relativa sencillez compositiva y eidética, desde el siglo XI, y sobre todo durante la Baja Edad Media, el tema iconográfico en estudio acrecentó de modo notable su complejidad morfológica y conceptual, mediante poéticos simbolismos y sutiles metáforas: tan significativo incremento - concluimos entonces - se hizo posible gracias a la progresiva devoción a la Virgen y al refinamiento argumental de la mariología, en inextricable vínculo con el hiper-desarrollo de la cristología.

Conforme a otra conclusión de nuestro acercamiento inicial, el claro protagonismo que, en casi todas las imágenes bajomedievales de La Anunciación, asume el ramo de lirios en manos del arcángel Gabriel o colocado en un florero o jarrón junto a la Virgen exige ser entendido con mayor perspicacia: ese ramo de lirios, en efecto, no encuentra satisfactoria explicación si se lo interpreta en el sentido genérico y abstracto de pureza o virginidad en general -ni siquiera aplicándolo expresamente a la Virgen María - tal como suelen hacerlo los especialistas en simbología e iconografía, al estilo de George Ferguson, Louis Réau, Juan-Eduardo Cirlot, Gertrud Schiller, MarieMadeleine Davy, James Hall, Hans Biedermann, Federico Revilla y Udo Becker .

Subrayamos además que la sobresaliente manifestación del ramo de lirios en casi todas las Anunciaciones bajomedievales obedece a que los programadores iconográficos de tales imágenes se inspiran en una larga y consistente tradición patrística y

2 José María SALVADOR GONZÁLEZ, "Flos de radice Iesse. Aproximación hermenéutica al motivo del lirio en la pintura gótica española de La Anunciación a la luz de fuentes patrísticas y teológicas”, Eikón / Imago, 4, julio-diciembre 2013, Madrid, Universidad Complutense de Madrid, pp. 183-222.

3 Santiago de la VORÁGINE, La Leyenda Dorada (Traducción del latín: Fray José Manuel Macías), Madrid, Alianza Editorial, Col. Alianza Forma, 29-30, 1990, 2 vols. 
teológica: de hecho, incontables autores eclesiásticos en la Edad Media "canonizan" la interpretación de ese elemento botánico - la flor brotada de un tallo- conforme a un simbolismo simultáneamente mariológico y cristológico, al identificar a Jesús con la flor y a María con el tallo.

Expusimos, por último, en aquel artículo las exégesis con las que numerosos $\mathrm{Pa}-$ dres de la Iglesia y teólogos medievales interpretan la profecía de Isaías sobre el florecimiento del tallo en la raíz de Jesé como una clara metáfora de la encarnación del Hijo de Dios (la flor) en el seno virginal de María (el tallo), quedando así justificado en primera instancia el simbolismo del ramo de lirios en las Anunciaciones medievales.

Tras esta breve síntesis de los principales resultados obtenidos en nuestra primera interpretación iconográfica del ramo de lirios en las Anunciaciones bajomedievales, partiendo de la exégesis de la flor brotada del tallo en la raíz de Jesé, hora es ya de emprender un segundo enfoque hermenéutico, desde la perspectiva de otra prefiguración veterotestamentaria.

\section{El ramo de lirios, una constante en la iconografía gótica española de $L a$ Anunciación}

En el arte gótico español, lo mismo que en el medieval europeo, las imágenes de la Anunciación con ramo de lirios son incontables. Ahora bien, para mejor focalizar el estudio iconográfico propuesto en el presente artículo, se han escogido aquí, para su análisis, diez pinturas góticas hispánicas representativas de dicho tema.

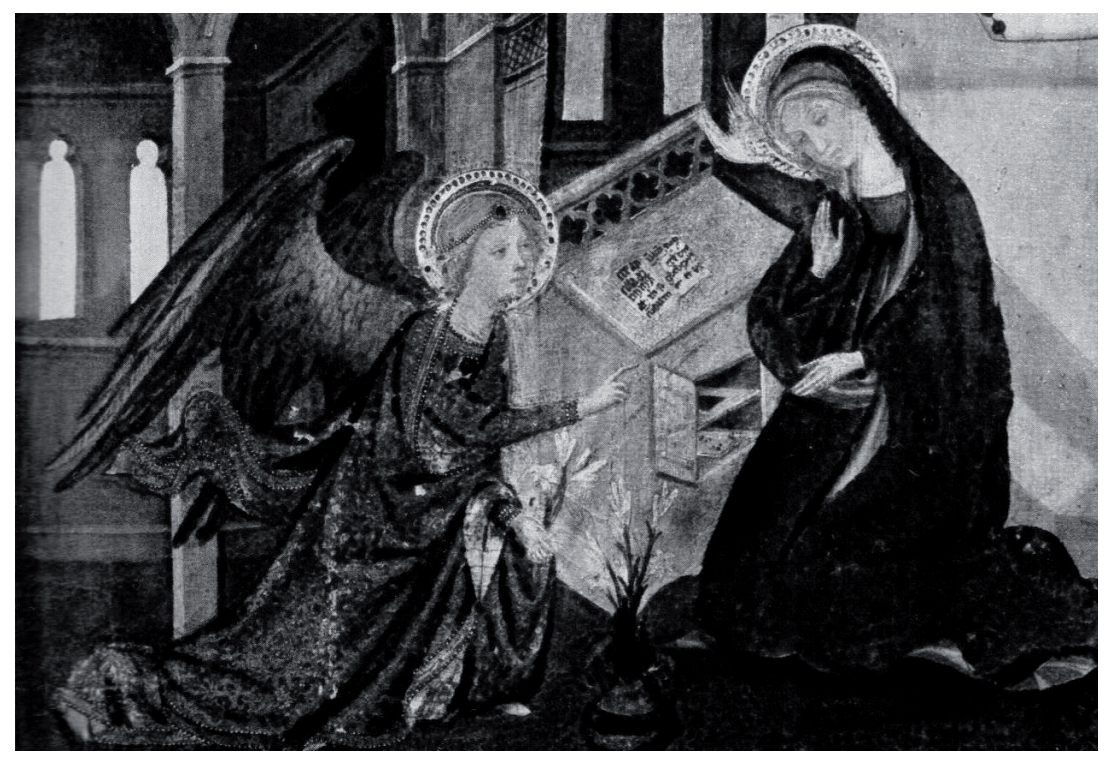

Fig. 1. Pere Serra, La Anunciación, panel de retablo de iglesia de Sant Llorenç de Morunys. 
Pere Serra (docum. 1357-1405), ${ }^{4}$ en su Anunciación en el retablo de la iglesia de Sant Llorenç de Morunys (Fig. 1) ${ }^{5}$ mantiene una estructura compositiva y narrativa bastante convencional. Cabizbaja y postrada de hinojos ante el enorme mueble -con doble función de escritorio y reclinatorio- sobre el que reposa su libro de oraciones, María entreabre sus brazos en gesto de timidez y recato. Apareciéndose por el lado izquierdo, el ángel Gabriel se arrodilla ante ella, apuntándola con el índice de la mano derecha para indicarle su elección divina como madre del Mesías. Al mismo tiempo el Espíritu Santo se dirige en vuelo hacia el oído de la Virgen, para significar que ella es fecundada por el divino Espíritu a través del oído (conceptio per aurem) en el mismo instante de escuchar el anuncio del ángel. Pere Serra introduce, no obstante, un detalle de interés, por lo infrecuente: plasma aquí al ángel portando en su mano izquierda un ramo de lirios, en perfecto paralelismo con otros ramos de la misma flor dispuestos en el gran jarrón que conecta en primer plano a los dos protagonistas del suceso. Mediante ese redundante paralelismo entre ambos equivalentes ramos pareciera querer reforzarse los significados simbólicos que, como se verá luego, encierran tales flores.

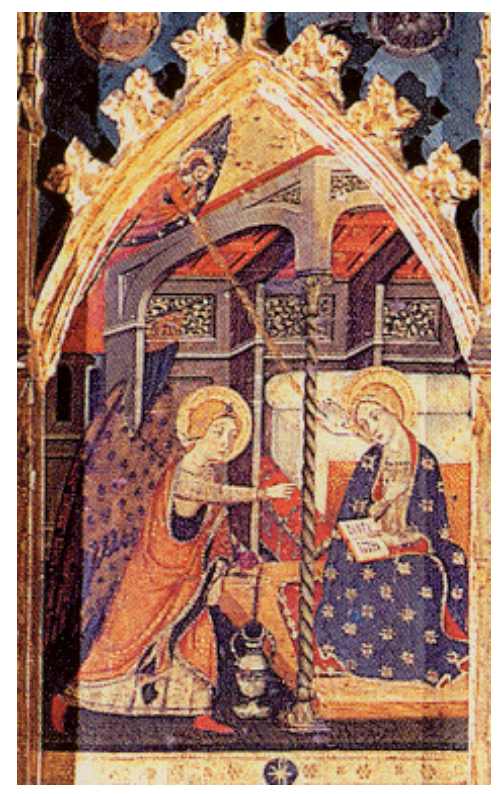

Fig. 2. Maestro de Sigena, La Anunciación, panel del Retablo de Sigena.

\footnotetext{
4 Para una amplia biografía de Pere Serra, con numerosos datos documentales, véase Josep GUDIOL y Santiago ALCOLEA I BLANCH, Pintura gótica catalana, Barcelona, Ediciones Polígrafa, 1986, pp. 5557. Para las biografías de muchos de los artistas incluidos en el presente artículo, véase también María del Carmen LACARRA DUCAY (Coord.), La pintura gótica durante el siglo XV en tierras de Aragón y en otros territorios peninsulares, Zaragoza, Institución Fernando el Católico (CSIC), Col. Actas Arte, 2007, 373 pp.

5 Pere Serra, La Anunciación, temple sobre tabla, panel de retablo de la iglesia parroquial de Sant Llorenç de Morunys (Solsonès). Rep. en GUDIOL, ALCOLEA 1986, p. 311, fig. 265 (conjunto del retablo) y fig. 268 (La Anunciación). En este libro la imagen de La Anunciación aparece incompleta, cortada bastante por arriba $\mathrm{y}$ un poco por abajo.
} 
También el Maestro de Sigena -identificado por muchos especialistas con Jaume Serra, o con alguno de sus hermanos, Pere o Francesc Serra ${ }^{6}$ - estructura su Anunciación (Fig. 2) del Retablo de Sigena, ${ }^{7}$ c. 1362-1375, o c. 1367-1381, según un modelo que, aun conservando ciertas analogías con el del recién analizado de Pere Serra, exhibe también notables diferencias respecto a este. ${ }^{8}$ Las similitudes consisten, sobre todo, en el vuelo de la paloma del Espíritu Santo hacia la oreja de la Virgen, la ubicación de esta junto al lecho y el porte de un ramo de flores por parte del ángel, en redundancia con el ramo de lirios emergente del florero en primer plano. No obstante, las variantes que el Maestro de Sigena introduce en su tabla con respecto al precedente esquema de Pere Serra son mucho más numerosas e importantes. En vez de situar de rodillas a ambos protagonistas, como hizo Pere Serra, el Maestro de Sigena plasma aquí a María sentada con recato, con el libro abierto sobre su regazo (en ausencia de escritorio/reclinatorio), mientras dispone al arcángel con los pies sobre el suelo y muy separados entre sí, para traducir el gesto de aterrizar en su vuelo o el de irrumpir con premura en la habitación para comunicar su mensaje celestial a la doncella. Además, en la parte superior izquierda del cuadro, por fuera de la casa de María, Dios Padre, de medio cuerpo en su esplendente mandorla, lanza con su mano derecha el rayo de luz, cuya estela recorre en vuelo el divino Espíritu, fecundador de la Virgen.

Jaume Cirera y Bernat Despuig ${ }^{9}$ combinan en su Anunciación del Retablo de San Miguel y San Pedro, en la iglesia de San Miguel de la Seu d'Urgell, ${ }^{10}$ 1432-33 (Fig. $3)$, elementos que lucían dispersos en los dos cuadros antes analizados. ${ }^{11}$ Así, en la

6 Esa posible atribución a alguno de los hermanos Serra es sugerida, por ejemplo, por GUDIOL, ALCOLEA 1986, p. 52, n 110.

7 Repr. en GUDIOL, ALCOLEA 1986, pp. 224, fig. 18. Ambos autores atribuyen este retablo al anónimo Maestro de Sigena (Ibid.).

8 Sobre este retablo GUDIOL, ALCOLEA presentan estos útiles datos historiográficos: "Pintada sobre el retrato de fr. Fortaner de Glera aparece la siguiente inscripción: "FRA ! FORTANER ! D ! GLRA : COMNADOR ! D : SIXENA :" De este prelado sabemos que en 1352 (15 dic.) era vicario de Sena, población que formaba parte del patrimonio del vecino monasterio de Sixena. Continuaba ostentando este cargo en 1357 (21 oct.), cuando actuó como procurador de la reina Elionor. En 1365 (21 abr.) figura ya con el título de comendador y procurador del monasterio de Sixena, señalándose que los poderes como procurador los había recibido en 1363 ( 5 ene.). En la pintura de este retablo se aprecia la colaboración de un segundo artista que podría ser Jaume Serra. Si ello fuera cierto, constituiría un nuevo argumento a favor de la identificación del Maestro de Sixena con Francesc Serra, hermano mayor del mencionado Jaume." (GUDIOL, ALCOLEA 1986, p. $\left.52, \mathrm{n}^{\circ} 110\right)$.

9 Para un bosquejo biográfico de Bernat Despuig y de Jaume Cirera, véase GUDIOL, ALCOLEA 1986, pp. 135-136.

10 Jaume Cirera y Bernat Despuig, La Anunciación, panel del Retablo de San Miguel y San Pedro, retablo mayor de la iglesia de San Miguel de la Seu d'Urgell (Alt Urgell), 1432-1433. Repr. en GUDIOL, ALCOLEA 1986, p. 399, fig. 694.

11 Sobre los avatares sufridos por este retablo a lo largo del tiempo, GUDIOL, ALCOLEA brindan estos interesantes datos: "En el Museo de Arte de Cataluña se conservan, de este retablo, "La caída de los demonios", el compartimiento principal y, flanqueando a este último, dos compartimientos laterales dedicados a San Miguel y otros dos dedicados a san Pedro. En la reconstrucción del conjunto del retablo que ofrecemos en la fig. 694 se ha respetado el actual emplazamiento de los compartimientos laterales del Museo de Arte de Cataluña, a pesar de que no se corresponde con la disposición que se aprecia en una antigua fotografía, publicada por Madurell, de cuando el retablo aún se encontraba en el templo para el que fue pintado. De todas formas conviene observar que, en el momento en que fue tomada dicha fotografía, el retablo había sufrido ya algunas modificaciones. Así, el ángulo de los cuerpos laterales exteriores respecto al plano general del retablo 
cimera de la tabla, emergiendo en busto en su tupida orla de querubines, Dios Padre emite por su boca el hálito de vida que da existencia humana al Hijo de Dios en el seno de aquella doncella, hacia cuyo oído vuela en comba el Espíritu divino. Mientras tanto, tres exuberantes ramos de lirios, emergentes de un enorme florero en primer plano - evidente vínculo simbólico entre ambos protagonistas del anuncio- metaforizan la encarnación del Redentor en el vientre de la Virgen, quien, de hinojos ante su libro de oraciones, recibe con asombro el mensaje del ángel, arrodillado con reverencia ante la recién inaugurada Madre de Dios.

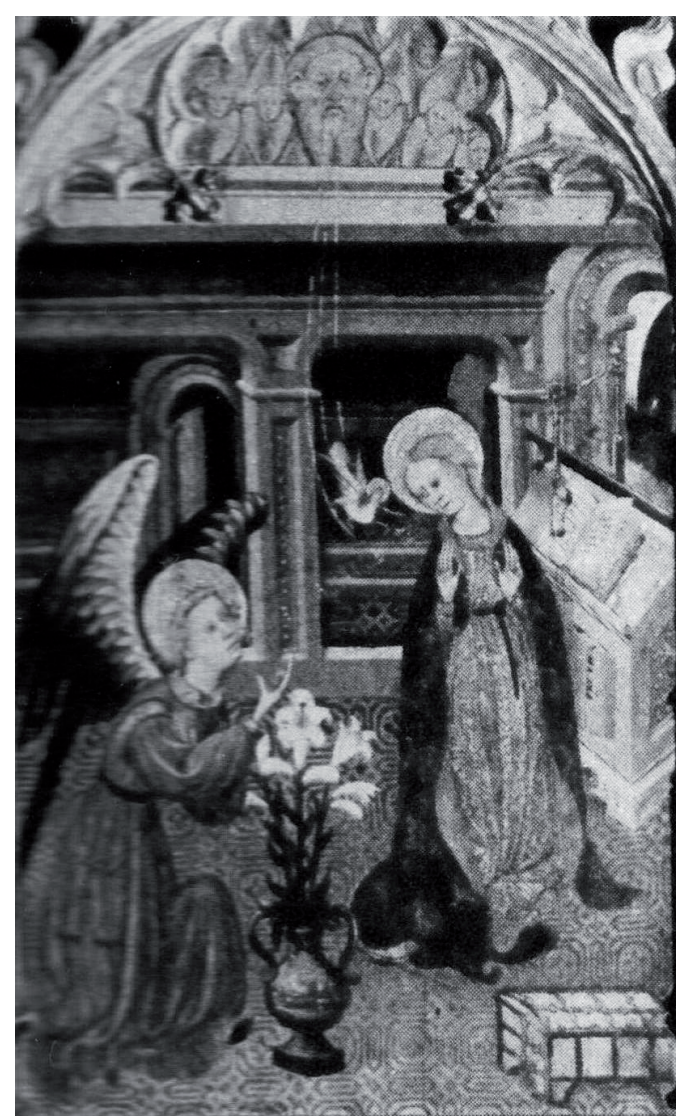

Fig. 3. Jaume Cirera y Bernat Despuig, La Anunciacion, panel del Retablo de San Miguel y San Pedro, iglesia de San Miguel de la Seu d'Urgell, 1432-1433.

no es propio de las estructuras de mediados del siglo XV. Más evidente, brutal incluso, fue la intervención sobre la predela, compuesta por dos tablas con tres compartimientos cada una: los respectivos compartimientos internos fueron aserrados verticalmente por la mitad y los fragmentos que quedaron separados fueron colocados, también en ángulo, uno a cada extremo de la predela. Tales modificaciones permiten suponer que, en algún momento, el retablo fue trasladado de su emplazamiento original a otro lugar más angosto, siendo preciso adaptar la estructura a las nuevas dimensiones del espacio.” (GUDIOL, ALCOLEA 1986, p. 136, nº 403). 


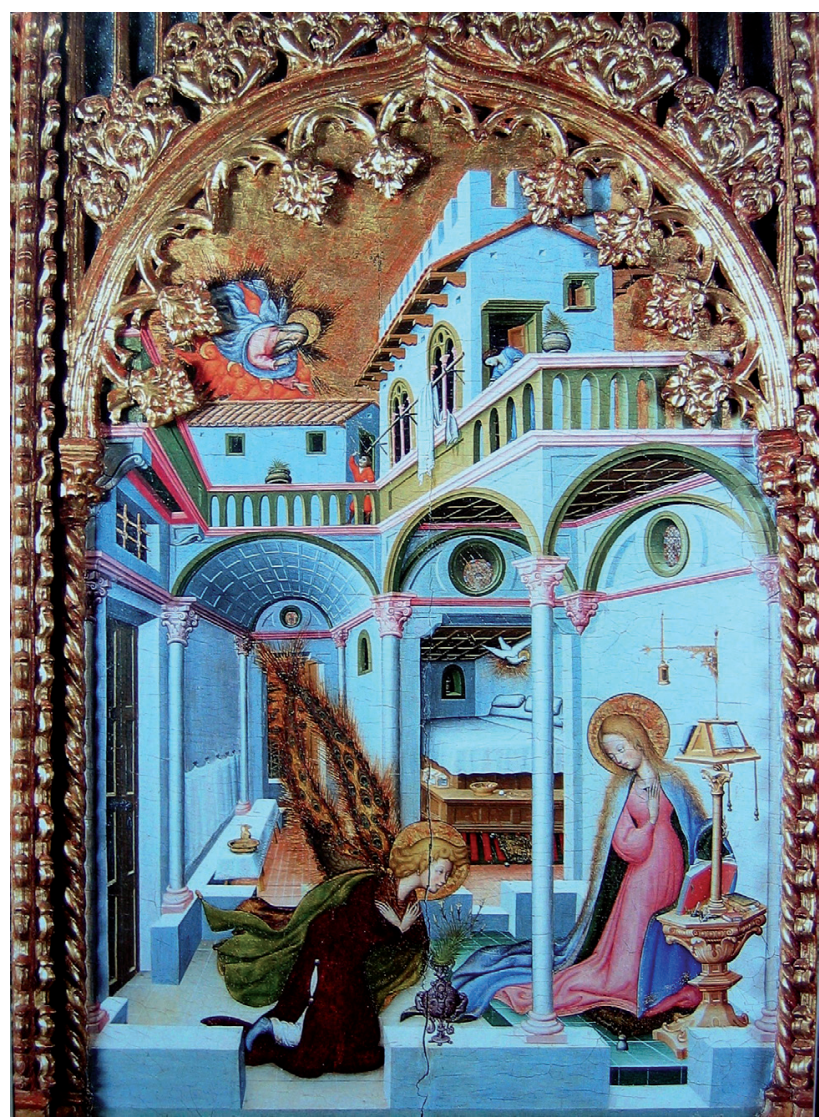

Fig. 4. Dello Delli, La Anunciación, panel del Retablo mayor de la Catedral Vieja de Salamanca, c. 1430-1450.

Dello Delli ${ }^{12}$ (con la ayuda de sus hermanos Nicolás y Sansón), ${ }^{13}$ en La Anunciación (Fig. 4) ${ }^{14}$ del Retablo de la Catedral Vieja de Salamanca, ${ }^{15}$ c. $1430-1450,{ }^{16}$ adopta una

12 Para una abundante biografía de Dello Delli, véase Francisco Javier PANERA CUEVAS, El retablo de la Catedral Vieja de Salamanca, Salamanca, Caja Duero, 2000, 397 pp.

13 Fernando GUTIÉRREZ BAÑOS ("La pintura gótica en la Corona de Castilla en la primera mitad del siglo XV: La recepción de las corrientes internacionales", en LACARRA DUCAY 2007, pp. 118-136) afirma que el retablo es obra de los tres hermanos Delli (Daniel, Nicolás y Sansón), lo cual explica las evidentes diferencias estilísticas en muchos de esos cuadros del retablo. Según este historiador, "Daniel Florentino, esto es Dello Delli, era el mayor de los hermanos Delli). (Ibid., p. 121).

14 Dello Delli (con la ayuda de sus hermanos Nicolás y Sansón Delli), La Anunciación, panel en el Retablo de la Catedral Vieja de Salamanca, c. 1430-1450. Repr. en PANERA CUEVAS 2000, pp. 117 (conjunto), y 118-118 (escena central).

15 En su amplia monografía PANERA CUEVAS (2000) realiza un pormenorizado estudio de este retablo de la vieja catedral salmantina. Ese retablo lo estudia también GUTIÉRREZ BAÑOS (2007, pp. 118-136).

16 Fernando GUTIÉRREZ BAÑOS (2007, pp. 128 y 120) data ese retablo salmantino entre 1438 (considerado el término post quem, por el documento de don Sancho de Castilla manifestando su voluntad de 
estructura compositiva de gran complejidad y notable artificio, con no pocos pormenores de interés narrativo. En la parte superior izquierda del panel, irrumpiendo desde el cielo en su nimbo de querubines, Dios Padre lanza por su boca el rayo/aliento de vida, cuyo resplandor parece incrementarse bajo el cuerpo de la paloma del Espíritu Santo, en vuelo hacia el oído de la Virgen. Esta, arrodillada en devota plegaria ante un extraño reclinatorio/facistol, recibe el respetuoso homenaje del mensajero celeste, quien se inclina con reverencia ante ella en señal de sumisión ante su Soberana. Por si fuera poco, el pintor introduce numerosos ingredientes decorativos y anecdóticos. La casa de la humilde muchacha nazarena luce como un lujoso palacio renacentista, de problemáticas perspectivas, pleno de enseres cotidianos, como la jofaina sobre la mesa en el recinto abovedado, la cesta de labores junto al lecho en la alcoba, o las macetas y la ropa que cuelgan en la balconada superior. Como era previsible, en ese contexto doméstico-palaciego juega su consabido papel primordial un precioso florero con lirios, en primer plano sobre el pretil. Con similar propósito anecdótico, Delli sitúa en el segundo piso del caprichoso edificio un par de fisgones contemplando la compleja escena: un muchacho, vestido de rojo, mira con sorpresa la aparición de Dios Padre, mientras una joven vestida de azul observa al arcángel, de vistosas alas con plumaje de pavo real. Así la interpretación del tema por Delli resulta, a la postre, condimentada con una alta dosis de decorativa cotidianidad anecdótica.

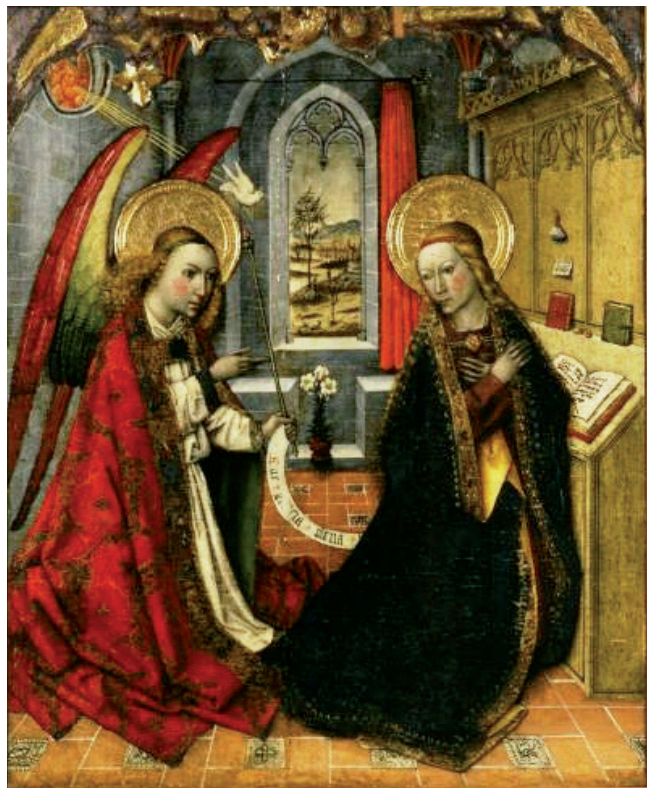

Fig. 5. Jaume Huguet, La Anunciación, panel del Retablo de la Madre de Dios, procedente de Vallmoll, c. 1450. Museu Diocesà de Tarragona.

ser sepultado en la capilla mayor de la catedral vieja de Salamanca) y 1445 (considerado el término ante quem, por el contrato por el que el cabildo salmantino se compromete a pagar a Nicolás Nelli 75.000 maravedíes por haber pintado al fresco la bóveda del ábside mayor sobre el retablo recién colocado). 
Jaume Huguet (c. 1415-1419), ${ }^{17}$ en La Anunciación del Retablo de la Madre de Dios, pintado hacia 1450 para la iglesia de Vallmoll, y hoy en el Museu Diocesà de Tarragona (Fig. 5) ${ }^{18}$ introduce una serie de recursos de especial atractivo. Revestido con lujosa capa pluvial de púrpura con brocado, el rubicundo arcángel porta un largo cetro lisado en su mano izquierda, desde la que despliega, a su vez, una banda con la salutación inscrita en ella: interesante, en tal sentido, es la decisión del pintor al interconectar a los dos protagonistas mediante esa filacteria, tal vez para ilustrar mejor el diálogo entre ambos, metaforizado precisamente por semejante soporte epigráfico. Además, de rodillas en su reclinatorio, cubierta con rica capa y con las manos cruzadas sobre el pecho, la Virgen vuelve con ti

midez su mirada hacia el visitante, separándola del libro de oraciones abierto sobre el facistol. Mientras tanto, en el exterior de la casa - con apariencia de capilla góticade la doncella, Dios Padre, circundado por rojos querubines, insufla por la ventana circular el soplo de vida, portador de la paloma del divino Espíritu, que vuela raudo hacia la cabeza de María para fecundarla per aurem. A guisa de elocuente recurso, Huguet coloca en pleno centro de la composición, por encima de la filacteria y bajo el alféizar de la gótica ventana, un voluminoso ramo con tres lirios, que, además de interrelacionar a los dos dialogantes -0 , para ser más exactos, los contenidos de sus respectivos discursos-, establece un claro nexo simbólico con el paisaje impoluto que se entrevé por la ve

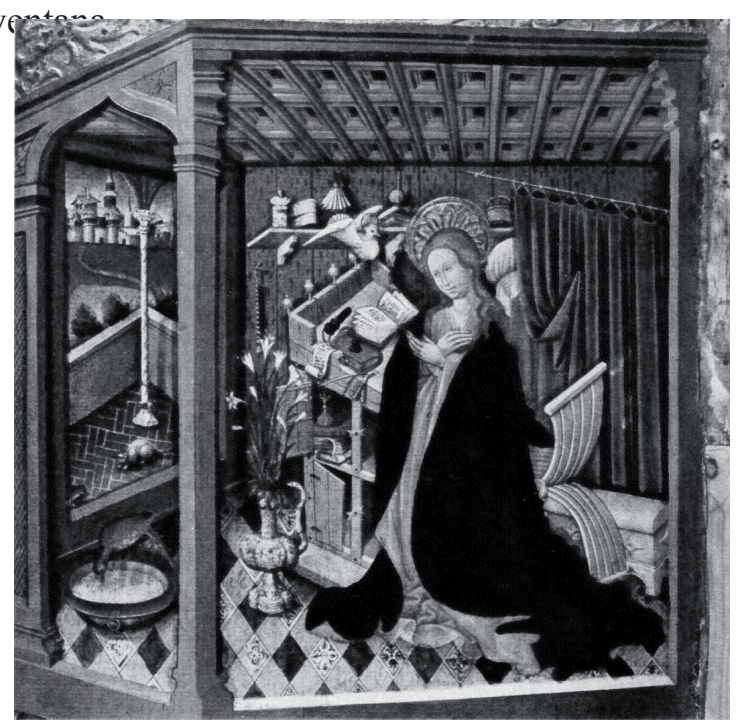

17 Para una amplia biografía de Jaume Huguet, con abundantes datos documentales, véase GUDIOL, ALCOLEA 1986, pp. 160-169.

18 Jaume Huguet, La Anunciación, panel del Retablo de la Madre de Dios, procedente de la iglesia parroquial de Vallmoll (Alt Camp), c. 1450, temple sobre tabla, 97 x $77 \mathrm{~cm}$. Museu Diocesà de Tarragona (inv. N 2.953). Repr. en GUDIOL, ALCOLEA 1986, p. 415, fig. 780. 
Fig. 6. Jaume Ferrer II, La Anunciación, panel del Retaule de la Verge dels Paers, Lérida, c. 1450-1455.

Jaume Ferrer II (docum. 1430-1457), ${ }^{19}$ al representar La Anunciación en el Retaule de la Verge dels Paers en la capilla de la Paeria, Lérida, c. 1450-1455 (Fig. 6) ${ }^{20}$ separa a los dos protagonistas en dos tablas independientes, situadas en la parte superior del ala izquierda (el arcángel Gabriel) y en la cima del ala derecha (la Virgen). Sin embargo, pese a su evidente relación narrativa, ambas tablas no guardan entre sí ninguna relación compositiva, ni por la forma de sus respectivas escenografías ni por la orientación de las mismas. ${ }^{21}$ En la primera de esas dos tablas (cuya imagen no se reproduce en este artículo), contra un sintético trasfondo arquitectónico visto en posición frontal, el pintor sitúa a un gran arcángel de vistosas alas, que, en pie, despliega frente a sí una inmensa y serpenteante cinta, con la congratulación angélica inscrita en ella. En el panel derecho, en cambio, Jaume Ferrer II plasma de rodillas a la Virgen, quien, con las manos cruzadas sobre el pecho y separando sus ojos del libro de oraciones, se inclina con parsimonia ante el Espíritu Santo al aproximarse en vuelo a su cabeza. No carece de interés el hecho de que en este cuadro el pintor, además de suprimir el rayo divino y la presencia de Dios Padre, introduce en la escenografía arquitectónica, de aberrante perspectiva, un variado conjunto de detalles cotidianos: de tal índole son los instrumentos de escritura y lectura en el escritorio, los enseres domésticos sobre la repisa, o las cortinas para garantizar la intimidad del lecho, como asimismo una serie de peripecias anecdóticas, como el gato persiguiendo a un ratón en el espacio exterior o el ave bebiendo en una jofaina. En todo caso, el artista coloca también aquí en céntrico lugar en primer plano un frondoso mazo de lirios, que surgen del estrecho cuello de un fino jarrón.

\footnotetext{
19 Para una biografía de Jaume Ferrer II, con numerosos datos documentales, véase GUDIOL, ALCOLEA 1986, p. 141.

20 Jaume Ferrer II, La Anunciación, panel del retablo de la capilla de la "Paeria" (Segrià), Lérida, c. 14501455, temple sobre tabla, 360 × 290 cm. Repr. en GUDIOL, ALCOLEA 1986, p. 407, fig. 744.

21 Sobre este retablo GUDIOL, ALCOLEA apuntan los siguientes datos de interés: "La fecha del acondicionamiento de una de las estancias de la Casa de la Paeria de Lérida como capilla no se conoce con exactitud debido a la pérdida de los libros de actas del "Consell General" de Lérida correspondientes a los años 1445-1460. Hasta 1445 las elecciones a cargos municipales se celebraban en una lonja (llotja); a partir de 1460 dichas elecciones se celebraban en otra dependencia porque, tal como se hace constar, la mencionada lonja había sido adecuada como capilla. Algo más de precisión aporta el libro de "Prohomenies" correspondiente a los años 1453-1458, cuyo folio 7 recoge un acuerdo del 22 de agosto de 1453, según el cual se destinaban 40 sueldos (£ 2/—) “... per certa obra de la capella de la paheria...”, es decir que en 1453 se estaba trabajando en la capilla. Es de suponer que el retablo se pintara por esas fechas. Esta datación del retablo induce a descartar toda posible colaboración de Pere Teixidor al lado de Jaume Ferrer II. La última mención documental conocida de Teixidor es de 1441, a casi una década de la hipotética fecha de ejecución del retablo. Si además consideramos su dilatada carrera de más de 40 años, resulta difícil que se mantuviera en activo en dicha fecha." (GUDIOL, ALCOLEA 1986, pp. 151-152, nº 442).
} 


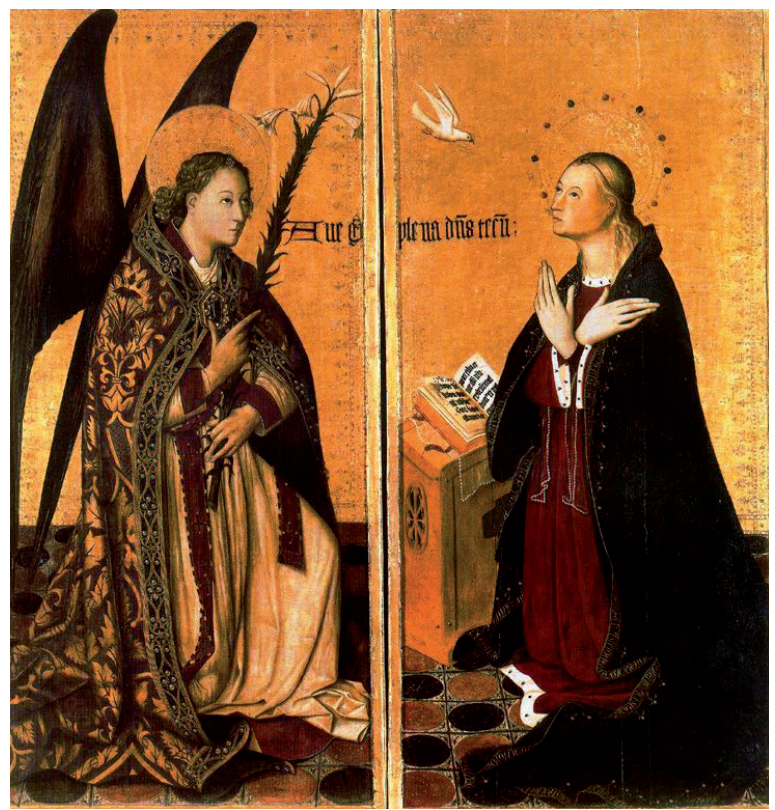

Fig. 7. Jaume Jacomart (o Lluís Dalmau), La Anunciación, c. 1411-1461. Museo de Bellas Artes, Valencia.

Jaume Jacomart (o, según otros expertos, Lluís Dalmau), en La Anunciación, c. 1411-1461, ${ }^{22}$ del Museo de Bellas Artes de Valencia (Fig. 7), ${ }^{23}$ plantea una solución compositiva radicalmente diferente a la de los otros artistas que estamos analizando. De hecho, al optar por un abstracto fondo de pan de oro, contra el que el pavimento viene a impactar en brusca ruptura, el artista prescinde de todo elemento escenográfico, pues solo se permite incluir como accesorio indispensable el reclinatorio/atril ante el que reza María. Sin embargo, la novedad más notable introducida por el pintor en esta obra -dividida en dos tablas, cada una de ellas ocupada por uno u otro de los protagonistas- es la circunstancia de que el tallo de lirios, de tamaño desmesurado, no se encuentra en un florero o jarrón, como casi siempre ocurre, sino que es llevado por el ángel como si de un cayado de heraldo se tratase: ese gesto de traer y entregar a la Virgen el ramo de lirios metaforiza a todas luces la voluntad divina transmitida por el ángel, según la cual ella es elegida para que la encarnación humana del Hijo de Dios (la flor) brote en su seno virginal (el tallo). Por lo demás, si bien el artista representa

22 Por ejemplo, Josep GUDIOL RICART (Pintura gótica, vol. 9 de Ars Hispaniae. Historia Universal del Arte Hispánico, Madrid, Plus Ultra, 1955, p. 242, fig. 206 y 207) asigna esta obra a Lluis Dalmau. Por su parte, Francesc RUIZ QUESADA ("Lluís Dalmau y la influencia del realismo flamenco en Cataluña", en LACARRA DUCAY 1007, pp. 271 y 293, repr. p. 293, fig. 25) lo asigna al Maestro de Bonastre, sobre quien plantea la posibilidad de poder identificarlo con Jacomart.

23 Jaume Jacomart (o Lluís Dalmau), La Anunciación, c. 1411-1461. Museo de Bellas Artes, Valencia. 
a María convencionalmente arrodillada con las manos cruzadas sobre el pecho, le da, sin embargo, otra expresión anímica: en vez de imaginarla cabizbaja y temerosa, la plasma confiada y decidida, elevando sus ojos hacia la paloma del Espíritu Santo, que vuela hacia ella en ausencia del rayo divino. Vinculando a ambos personajes, sin el soporte de la hạitual filacteria una incorinción eniorráfica nregona la salutación laudatoria de $\mathrm{Gab}$

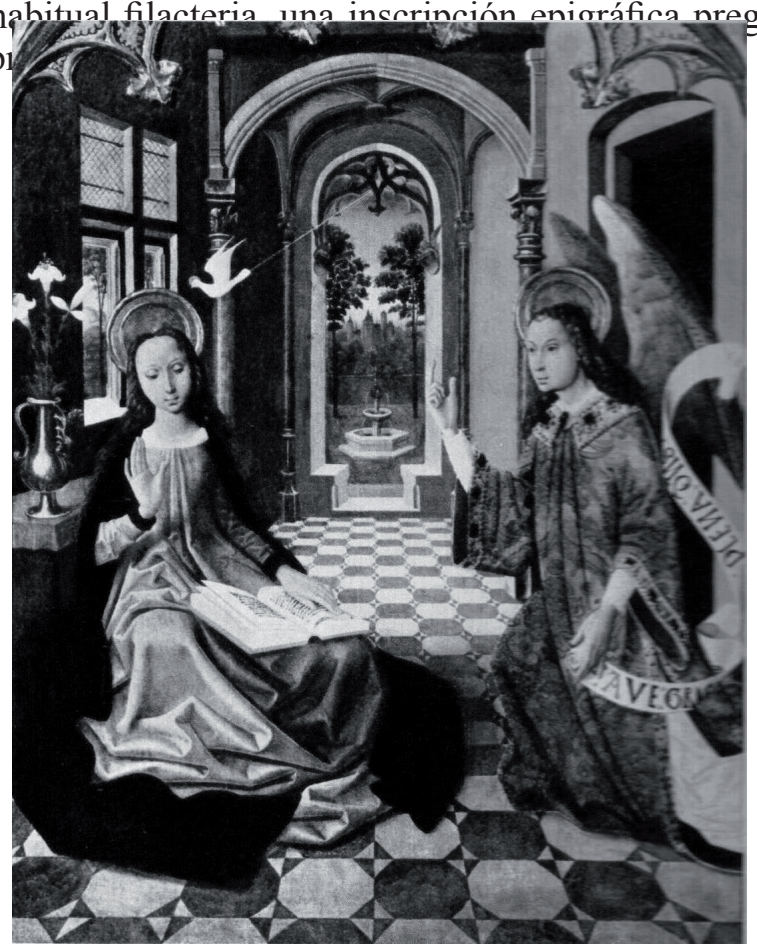

Fig. 8. Maestro de Canapost, La Anunciación, panel del Retablo de Puigcerdà, MNAC, Barcelona.

El Maestro de Canapost ${ }^{24}$ desarrolla en La Anunciación del Retablo de Puigcer$d \grave{a}^{25}$ una cierta complejidad compositiva. ${ }^{26}$ Además de diseñar la residencia de María como un espléndido palacio, abierto al fondo hacia un frondoso jardín con una

\footnotetext{
24 Para un breve apunte biográfico del Maestro de Canapost, véase GUDIOL, ALCOLEA 1986, p. 200.

25 Maestro de Canapost, La Anunciación, panel de Retablo de Puigcerdà (Baixa Cerdanya), 220 x 130 cm. MNAC, Barcelona (inv. No 24.078). Repr. en GUDIOL, ALCOLEA 1986, p. 453, fig. 1011.

26 GUDIOL, ALCOLEA (1986, p. 201, nº 657) ofrecen estos datos históricos sobre el retablo de Puigcerdá: "Cuando fueron adquiridos para el Museo de Barcelona, el san Jerónimo se encontraba en la iglesia parroquial de Puigcerdà, mientras que la Anunciación estaba en la capilla de Nuestra Señora de la Gracia de esa ciudad. No se conoce su emplazamiento original. De todas formas, creemos interesante recoger la observación de Cayetano Barraquer, según la cual "Muchos de los cuadros góticos, existentes en Puigcerdà en su iglesia parroquial y en la capilla de Gracia, provienen de los retablos que ornaban a (la iglesia del convento de) Santo Domingo antes del decreto de exclaustración de 1835."
} 
fuente en el centro -en clara referencia simbólica a María como hortus conclusus y fons signatus-, el pintor, contrariando el clásico modelo compositivo adoptado por la mayoría de los artistas en sus Anunciaciones, invierte aquí la posición de ambos protagonistas: el ángel aparece ahora por la derecha, mientras la Virgen se halla en la parte izquierda. Tras ingresar a la casa por la puerta abierta, Gabriel comunica de rodillas su mensaje a María señalando hacia arriba con el índice de su mano derecha, para indicarle que su mensaje proviene del Altísimo, mientras con su mano izquierda despliega su cimbreante cinta con el enaltecedor saludo Ave gratia plena dns inscrito en ella. La Virgen, que, sentada con recato y sumiso gesto cabizbajo, mantiene abierto con la mano izquierda el libro de plegarias sobre sus piernas, levanta su diestra en actitud de aceptar -como en el ritual del juramento- la inescrutable voluntad divina que le transmite el mensajero celeste. Sobre su cabeza vuela en forma de paloma el Espíritu Santo, deslizándose por el oblicuo rayo fecundador que el Todopoderoso envía a la doncella para fertilizarla. Al lado de la humilde ancilla Domini, sobre un mueble, surge de un florero un exuberante ramo de níveos lirios, que, en perfecta simetría con la blanca paloma, establecen con esta un vínculo cromático y conceptual en torno a la cabeza de la ndencia con los profundos contenidos dogmáticos qu lirios, como se explicará lı

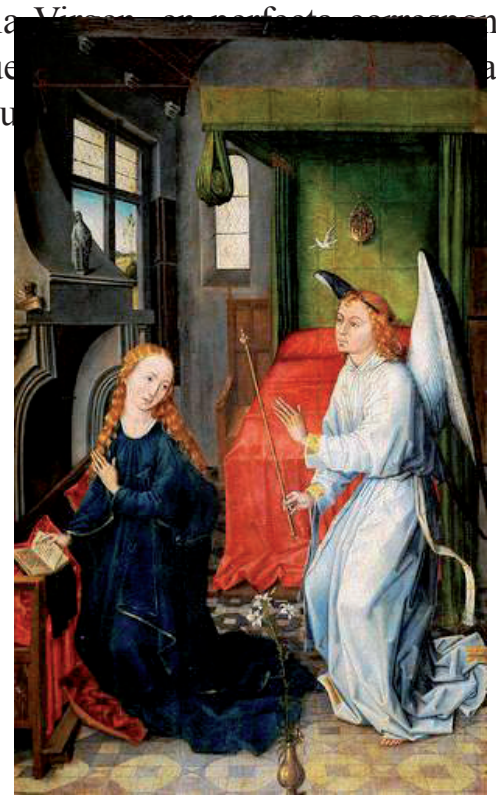
Anunciación con ramo de

Fig. 9. Maestro de Sopetrán, La Anunciación, fines s. XV. Museo del Prado, Madrid. 
Tal como lo hizo el Maestro de Canapost en la tabla recién analizada, también el Maestro de Sopetrán ${ }^{27}$ invierte las posiciones de ambos protagonistas en su Anunciación del Museo del Prado $^{28}$ (Fig. 9) ${ }^{29}$ Portando un cetro/cayado lisado, el arcángel aparece por la derecha, iniciando el gesto de arrodillarse ante la Virgen, mientras esta permanece de hinojos en la parte izquierda del cuadro, ante el libro de oraciones, cuyas páginas mantiene abiertas con su mano derecha. En esa pulcra habitación burguesa de la doncella -donde no faltan elementos tan simbólicos como el lecho (fecundación/concepción) y las acristaladas ventanas por las que penetra la luz (maternidad virginal: como el rayo de luz que atraviesa el cristal sin romperlo ni mancharlo)- vuela al fondo sobre el lecho la paloma del Espíritu Santo, mientras en primer plano un enhiesto ramo de lirios emergiendo de un florero despliega en su cúspide tres blancas

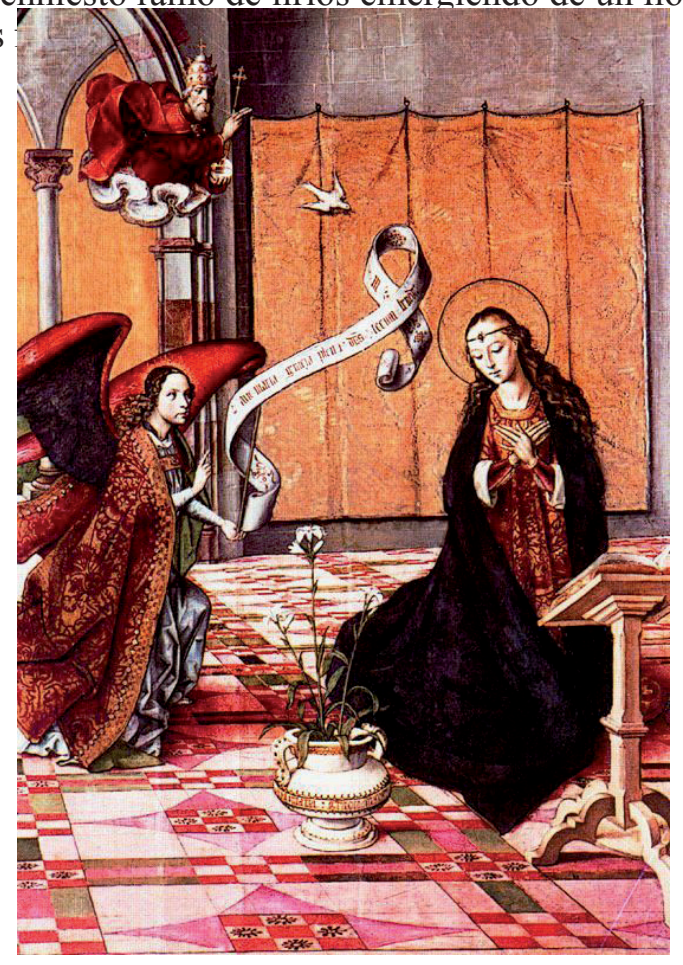

27 Para un estudio de la vida y obra del Maestro de Sopetrán, véase Pilar SILVA MAROTO, "Pintura hispanoflamenca castellana. De Toledo a Guadalajara: El foco toledano”, en LACARRA DUCAY 2007, pp. 305-308.

28 Maestro de Sopetrán, La Anunciación, fines s. XV. Museo del Prado, Madrid. Repr. en VV.AA., Bartolomé Bermejo y su época. La pintura gótica hispanoflamenca (cat. exp.), Museu Nacional d'Art de Catalunya, Barcelona / Museo de Bellas Artes de Bilbao, 2003, p. 80; y en SILVA MAROTO 2007, p. 326, fig. 3.

29 Sobre el estilo del Maestro de Sopetrán en este cuadro y en otras obras de su producción, véase el comentario de SILVA MAROTO 2007, pp. 307-308. 
Fig. 10. Pedro Berruguete, La Anunciación, iglesia de Paredes de Nava (Palencia).

Pedro Berruguete (c. 1450-1503) estructura su Anunciación de la iglesia de Paredes de Nava, Palencia (Fig. 10), ${ }^{30}$ de forma clara y sucinta, sin renunciar a ciertos elementos simbólicos. Revestido con espléndida capa pluvial, el vistoso arcángel, en insólito malabarismo, sostiene sobre su abierta mano izquierda un largo cetro/cayado, junto al que despliega la serpenteante filacteria con la sólita alabanza inscrita $\mathrm{Ave} M a-$ ria gratia plena dns tecum bened (...) $m$, mientras con su mano derecha apunta hacia el Espíritu Santo, paloma en vuelo hacia la cabeza de la Virgen. Arrodillada ante el atril con los ojos entornados, esta inclina con modestia la cabeza y cruza las manos sobre el pecho, para expresar su obediencia de esclava ante los insondables designios divinos. Esa relación dialógica entre la divinidad que elige y la doncella que obedece se ilustra también mediante la presencia (de medio cuerpo sobre una orla de nubes) del Dios Todopoderoso, quien, revestido con henchida capa roja y tocado con la triple corona papal, bendice a María con su mano derecha, mientras sostiene con la izquierda la esfera crucífera del Universo. Una vez más, el contenido teológico que se dilucida en este diálogo a tres - la divinidad, su mensajero angélico y la doncella destinataria del mensaje celestial-se visualiza en la poderosa metáfora de los ramos de lirios que reposan en el enorme jarrón blanco situado en el centro del primer plano.

\section{El florecimiento de la vara seca de Aarón, metáfora de la encarnación de Dios Hijo en el seno virginal de María, según la tradición patrística y teológica}

La circunstancia de que el ramo de lirios adquiera tan protagónica presencia en casi todas las imágenes bajomedievales de La Anunciación, como las hasta aquí analizadas, se explica a cabalidad por estrictos motivos dogmáticos. A decir verdad, el contenido simbólico del ramo de lirios en tales imágenes se revela de manera clara y determinante a través de reiterativas y unánimes exégesis de Padres o Doctores de la Iglesia y teólogos medievales sobre dos pasajes del Antiguo Testamento: la profecía de Isaías sobre el florecimiento del tallo en la raíz de Jesé, y el florecimiento de la vara seca de Aarón. ${ }^{31}$

Como antes quedó dicho, interpretamos ya en otro trabajo previo el ramo de lirios en las imágenes de la Anunciación a la luz de los comentarios patrísticos y teológicos sobre la profecía de Isaías vaticinando el florecimiento del tallo brotado en la raíz de Jesé. ${ }^{32}$ El presente artículo abordará una serie de nuevas interpretaciones, conforme a las cuales no pocos Padres o Doctores de la Iglesia y teólogos medievales coinciden

30 Pedro Berruguete, La Anunciación, iglesia de Paredes de Nava (Palencia).

31 En el artículo José María SALVADOR GONZÁLEZ, "Flos campi et lilium convallium. Tercera interpretación del lirio en la iconografía de La Anunciación en el Trecento italiano a la luz de fuentes patrísticas y teológicas", Eikón Imago, no 5, enero-junio 2014, Madrid, Universidad Complutense de Madrid, pp. 7596, hemos precisado estos mismos significados dogmáticos, tal como son expuestos por numerosas exégesis patrísticas y teológicas sobre el referido versículo del Cantar de los Cantares.

32 Véase, José María SALVADOR GONZÁLEZ, "Flos de radice Iesse. Aproximación hermenéutica al motivo del lirio en la pintura gótica española de La Anunciación a la luz de fuentes patrísticas y 
en ver a Cristo y a María proféticamente figurados en otro pasaje del Antiguo Testamento: el referente a la vara seca de Aarón, que de manera súbita, por milagro divino, retoñó, floreció y dio frutos en la Tienda del Testimonio.

Ese prodigioso episodio es descrito así en Números, cuarto libro del Pentateuco:

Yahvé dijo a Moisés: "Habla a los israelitas. Que te den una rama por cada familia patriarcal: que entre todos los príncipes, en representación de sus familias patriarcales, te den doce ramas. Y escribe el nombre de cada uno en su rama. En la rama de Leví escribe el nombre de Aarón, pues ha de haber una sola rama para el jefe de la familia de Leví. Las depositarás en la Tienda del Encuentro, delante del Testimonio, donde me suelo manifestar a ti. El hombre cuya rama retoñe será el que yo elijo. Así dejarán de llegar hasta mí las murmuraciones que los israelitas profieren contra vosotros.” Moisés habló a los israelitas, y cada uno de los príncipes le dio una rama, doce ramas, en representación de todas las familias patriarcales. Entre sus ramas estaba también la rama de Aarón. Moisés depositó las ramas delante del Yahvé en la Tienda del Testimonio. Al día siguiente, cuando entró Moisés en la Tienda del Testimonio, vio que había retoñado la rama de Aarón, por la casa de Leví: le había brotado yemas, había florecido y había producido almendras. Moisés sacó todas las ramas de la presencia de Yahvé, ante los israelitas; las vieron, y tomaron cada uno su rama. Entonces dijo Yahvé a Moisés: "Vuelve a poner la rama de Aarón delante del Testimonio, para guardarla como señal para los rebeldes: acabará con las murmuraciones, que no llegarán ya hasta mí, y así no morirán." Moisés lo hizo así; como le había mandado Yahvé lo hizo. ${ }^{33}$

Ahora bien, para numerosos Padres, Doctores de la Iglesia y teólogos medievales tanto el florecimiento del tallo o vara en la raíz de Jesé como el de la vara seca de Aarón evidencian un doble simbolismo, simultáneamente mariológico y cristológico. A su juicio, en efecto, el tallo floreciente en la raíz de Jesé y la vara florecida de Aarón constituyen sutiles metáforas de María en su virginal maternidad divina (simbolismo mariológico), mientras la flor brotada en ese tallo en la raíz de Jesé o en esa vara de Aarón prefigura en poética analogía a Cristo en su encarnación en el seno de María (simbolismo cristológico). Esos dos simbolismos se manifiestan inextricablemente unidos, tal como lo ponen de relieve las concordantes exégesis de los prestigiosos autores eclesiásticos que discurren sobre el tema.

A la luz de tales premisas, ante la necesidad de plasmar en imágenes artísticas el decisivo acontecimiento de la Anunciación -en el que se garantiza la salvación de la Humanidad, gracias a la encarnación de Dios Hijo en el vientre de María-, los programadores del contenido conceptual de tales imágenes se inspiran en esa sólida tradición patrística y teológica que interpreta el florecimiento del tallo en la raíz de Jesé y el de la vara de Aarón como una doble prefiguración del engendramiento de Dios Hijo, encarnado en el seno virginal de María. Expuestos ya en nuestro anterior artículo las exégesis referidas a la primera figuración (la flor en la raíz de Jesé), pre-

teológicas", Eikón / Imago, 4 (2013 / 2), julio-diciembre 2013, Madrid, Universidad Complutense de Madrid, pp. 183-222.

33 Nm 17, 16-26. En Biblia de Jerusalén. Nueva edición revisada y aumentada, Bilbao, Desclée de Brouwer, 1998, p. 176. 
cisaremos ahora numerosas interpretaciones patrísticas y teológicas sobre la segunda prefiguración cristológico-mariológica: el florecimiento de la vara seca de Aarón.

Así, por ejemplo, San Fortunato de Aquilea († c. 304) refrenda en términos explícitos que la vara de Aarón florecida en el tabernáculo anticipa premonitoriamente a la Virgen María, y a Jesús como la flor y el fruto en ella brotados, en perfecto paralelismo con el ya referido vaticinio de Isaías sobre el florecimiento del tallo en la raíz de Jesé, y en plena concordancia con el otro dicho de Salomón calificando al Señor como la flor del campo y el lirio de los valles. ${ }^{34}$

Ideas similares expresa, casi tres generaciones más tarde, San Efrén de Siria (306373), para quien la florecida y fructificada rama seca de Aarón prefigura el vientre de María, que, siendo virgen, engendró y dio a luz a Jesús. ${ }^{35}$

Casi por los mismos años San Ambrosio (330-397), arzobispo de Milán, señala que el profeta anunció la milagrosa encarnación del Hijo de Dios al proferir "Surgiste, hijo mío, del retoño", por cuanto germinó del seno de la Virgen como un fruto de la tierra, y subió de las entrañas maternas como una flor de buen olor para la redención del mundo, conforme al presagio de Isaías sobre el florecimiento del tallo en la raíz de Jesé ${ }^{36} \mathrm{El}$ prelado milanés completa la idea afirmando que, si la raíz de Jesé es la estirpe judía, el tallo es María, y la flor de María es Cristo, de tal modo que ese tallo es de condición regia, de la casa y la patria de David, cuya flor es Cristo, quien limpió la suciedad mundana e infundió el olor de la vida eterna. ${ }^{37}$

No muy diferente es un siglo después el sentir de San Cromacio de Aquilea († c. 407), al referirse a la virginal María -engendradora de Jesús sin concurso varonilcomo prefigurada en la vara de Aarón, la cual, tras germinar, florecer y fructificar sin el nutriente humus de la tierra, fue depositada en el tabernáculo en signo de eterno recuerdo ${ }^{38} \mathrm{El}$ mismo santo insiste en la idea de que en la vara de Aarón, la cual sin el abono de la tierra germinó y produjo un fruto suavísimo, se manifiesta María, quien

34 "Virga Aaron, quae in Sancta Sanctorum floruit, in typum Domini flos et fructus ipse virgae accipere potest. In virga quippe Mariam Genitricem Domini nostri Iesu Christi, in flore vero ipsum Dominum praefigurasse accipiendum est. Sicut Scriptura ait: « Egredietur virga de radice Iesse (Is, 11, 1) ». Hinc de Domino Salomon ait: «Ego sum flos campi et lilia convallium (Cant. 2, 1 »." (FORTUNATO DE AQUILEA (FORTUNATUS AQUILEIENSIS), Commentarii in Evangelia I. En Sergio ALVAREZ CAMPOS, Corpus Marianum Patrísticum, Burgos, Aldecoa, 1974, vol. III, p. 20).

35 "Virga Aaronis germinavit aridusque truncus protulit fructum: eius symbolum invenit hodie explicationem. Venter est virginalis qui peperit..." (SAN EFREN DE SIRIA, Hymni de Nativitate 1, 17. En ALVAREZ CAMPOS 1970, vol. II, p. 477).

36 "Mirifice autem et incarnationem eius expressit, dicens: « Ex germine, fili mi, ascendisti, » eo quod tamquam frutex terrae in alvo Virginis germinavit, et ut flos boni odoris ad redemptionem mundi totius maternis visceribus splendore novae lucis emissus ascenderit". (SAN AMBROSIO, De Benedictionibus Patriarcharum. Liber Unus, IV, 19. PL 14, 713).

37 "Radix familia Iudaeorum, virga Maria, flos Mariae Christus. Recte virga quae regalis est generis, de domo et patria David, cuius flos Christus est, qui factorem mundanae colluvionis abolevit, et vitae aeternae odorem infudit." (Ibid.).

38 "Haec virga est quae in tabernaculo testimonii posita ad signum aeternae memoriae novo et miro mysterio sine humore terrae fructum nucis germinavit." (SAN CROMACIO DE AQUILEA, Homilia in Mattheum 1, 6. En ALVAREZ CAMPOS 1974, vol. III, p. 175). 
sin concurso varonil engendró un hijo, convertido en el fruto verdadero de la salvación humana. ${ }^{39}$

A fines del siglo IV el homilista Sedatus Nemausensis ( $\dagger$ c. 500) ratifica que, mediante el prodigio de que su vara seca echase hojas y produjese nueces, Aaron preanunció a Cristo como una flor nacida de un seno virginal..$^{40}$ Algunos decenios más tarde, el monje y teólogo sirio Severo de Antioquía (c. 475-538) afirma en una carta a Teodosio de Alejandría:

Hay constancia de que la vara de Aarón produjo hojas y almendras, con lo que se nos prefiguraba al Emmanuel, que es la vara del reino y que nació como de la raíz de Dios Padre, sin principio ni tiempo, y que reina con Él y con el Espíritu Santo sobre el cielo y la tierra. Y al fin de los días se encarnó y se hizo hombre, sin cambiar su naturaleza divina, y nació en carne humana de la raíz de Jesé y de David, de quienes desciende la Virgen María, la Madre de Dios. ${ }^{41}$

El escritor antioqueno argumenta luego que el tallo significa la germinación y la concepción de Jesús sin comercio carnal en el seno de la siempre Virgen María, pues la propiedad del tallo, como ornato natural de la raíz, es precisamente la de nacer sin cópula ni unión carnal. ${ }^{42}$ Por ello, en su poético Himno 119, Severo de Antioquía pone en relieve dos prefiguraciones bíblicas de la Virgen y su divino Hijo: compara, ante todo, a María - por su privilegio de ser la virginal Madre del Dios Hijo- con el Arca de la Alianza, construida con oro puro y maderas incorruptibles, y contenedora del vaso del maná; ${ }^{43}$ y luego reitera que Cristo se prefigura metafóricamente en la vara de Aarón, la cual, estando seca, germinó y echó frutos, pues el Hijo de Dios, al encarnarse, asumió y rejuveneció nuestra naturaleza, que había languidecido en la vejez por causa del pecado. ${ }^{44}$

39 "Et illic ergo in virga Aaron Maria ostendebatur, quae vere sine humore terrae fructum suavissimum germinavit; quia sine semine viri filium edidit, qui verus fructus humanae salutis effectus est (...). In virga autem singulari idcirco Maria cognoscitur, quia consortium viri nescivit.” (Ibid.).

40 "Sic Aaron in arida virga frondente et nuces proferente Christum virginalis uteri florem preanuntiavit." (SEDATUS NEMAUSENSIS, Sermo in Nativitate Domini. En ALVAREZ CAMPOS 1981, vol. VI, p. 193).

41 "Virgam autem Aaronis constat produxisse folia et amygdalas emisisse, in qua praesignificabatur nobis Emmanuel, qui est virga regni et quasi e radice Deo Patre ortus et natus est, sine principio et sine tempore et cum eo et cum Spiritu Sancto regnat in coelestia et in terrestria. In fine autem dierum propter nos incarnatus est et inhumanatus, sine mutatione et idem ipse ortus est a radice Iesse et Davidis secundum carnem, e quibus est Virgo Deigenitrix Maria..." (SEVERO DE ANTIOQUÍA, Epistula ad Theodosium Alexandrinum. En ALVAREZ CAMPOS 1979, vol. IV/2, pp. 38-39).

42 "Significat autem virga etiam germinationem et conceptionem absque semine, ex Maria sancta semperque Virgine. Proprietas enim est virgae ut ornatus e radice naturaliter, non autem e copulatione aut commixtione nascatur." (Ibid., p. 39).

43 "Tibi comparari merito potuit, o Deipara Virgo, tibique ut nomen attribui illud Foederis tabernaculum quod pone secundam cortinam latebat quodque Sancta Sanctorum appellabatur; quia retro ipsum exemplar Emmanuel habitavit in te et vixit, quia arcae instar auro puro lignisque incorruptis structae, constabat ex purissima Deipara et humanitate, munda prorsus nec corrupta, seminis experte, sicut panis qui de coelo descendit, in aureo vase et manna ibi posito adumbratus." (SEVERO DE ANTIOQUÍA, Hymnus 119. En ALVAREZ CAMPOS 1979, vol. IV/2, p. 59).

44 "Ipse etiam imitatus Aaronis virgam est, quae languescens germinavit fructumque fecit, quo per incarnationem assumpsit genus nostrum atque renovavit, quod propter peccatum vetustate consenuerat." 
Tal vez por esos mismos años, un autor anónimo, designado como el Pseudo Augustín (s. V-VI), señala que etimológicamente en latín "tallo" o "vara" (virga) suena casi igual que "virgen" (virgo), con una sola letra de diferencia, por lo cual del tallo (vara) deriva virgen.$^{45} \mathrm{El}$ ignoto autor amplía su exégesis al sostener que, si el profeta designa a la Virgen como un tallo, obedece a que María concibió y parió sin perder su virginidad. ${ }^{46} \mathrm{~A}$ partir de tales premisas, el Pseudo Augustín concluye que la flor regia (O florem regem !) brotada en ese tallo es la carne del Señor, que nació sin necesitar "el vicio del semen humano" (nata sine vitio humani seminis), al punto de que, así como aquel tallo (virga) no era un tallo, sino una Virgen (virgo), así aquella flor no es flor de un tallo, sino naturaleza humana o carne (caro), pues quien parió (María) a la flor hizo brotar carne (Cristo encarnado) proveniente del género humano (María). ${ }^{47}$

Un himnógrafo anónimo activo hacia el siglo VI señala que las Escrituras sagradas prefiguraron el engendramiento de Cristo en el seno de la Virgen como la vara de Aarón depositada en el Arca de la Alianza, vara que se cubrió de hojas, pese a no haber sido plantada ${ }^{48}$ Abundando en tal idea, el anónimo escritor concluye :

La vara [de Aarón] se coronó con hojas sin ninguna irrigación, para convertirse en figura de la virgen que produjo un fruto milagroso y nos lo dio a nosotros. La figura de esta Virgen está señalada y es conocida mediante la vara de los levitas. ${ }^{49}$

En el año 567 Teodosio I, patriarca de Alejandría entre 535-567, afirma que Cristo, mucho tiempo antes de nacer como Hijo de Dios encarnado, había sido ya anunciado por los profetas, pues Moisés lo llama Tabernáculo del Testimonio en el que floreció la vara de Aarón, Isaias vaticina su parto virginal, Jeremías lo llama vara de avellano, Ezequiel lo presenta como la puerta del Altísimo, y Daniel como el monte santo de Dios. ${ }^{50}$

Severo, patriarca de Antioquía (c. 462-518), comienza por recordar el hecho de que la vara de Aarón emitió hojas y produjo almendras, lo cual presignificaba al

(Ibid.).

45 "Si quidem ethymologiam huius nominis retractemus, virgo quasi virga: a virga virgo. Iamque intelligant ipsa sibi convenire vocabula, cum unius litterae differentia, hoc videatur virgo sonare quod virga." (PSEUDUS AUGUSTINUS, sive Sermones Caillau-Saint-Yves, In Natali Domini 1. En ALVAREZ CAMPOS 1981, vol. VI, p. 260).

46 "Volunt autem nosse a virga virginem designatam? (...) Virgo Maria, quae generi secundum carnem originique respondens, caro fuit quae virga fuit, sed virgo fuit, quae virgo concepit et peperit." (Ibid.).

47 "Flos iste caro est Domini, quae nata sine vitio humani seminis, florentem per omnia pulchritudinem retinet societatis... O florem regem! O florem iudicem! Sicut ergo virga illa non virga, sed virgo est, sic et flos ille non flos virgae, sed caro est. Quae florem quidem peperit, et ex genere carnis carnem emisit (...)." (Ibid.).

48 "Iidem [los libros sagrados] praefigurarunt te per virgam in arca repositam, quae, etsi non plantata, fronduit; ut generationem tuam illustraret." (HIMNÓGRAFO ANÓNIMO (c. siglo VI), Hymnus 4, 30. En ALVAREZ CAMPOS 1981, vol. V, p. 162).

49 "Virga absque irrigatione foliis coronata fuit, ut esset figura virginis quae fructum miraculosum produxit et dedit nobis. Huius virginis figura signata notaque est in virga levitarum." (Ibid.).

50 "Sed qui propheta nobis hunc non nuntiavit honorem ante multo quam nasceret? Moises te appellat tabernaculum Testimonii in quo nobis virga Aaronis effloruerit. Isaias tuum nobis virginalem partum nuntiat, Hieremias te appellat virgam coryli, Ezechiel Altissimi portam, Daniel montem Dei sanctum." (THEODOSIUS ALEXANDRINUS, Sermo quem dixit Pater noster ter beatus Abbas Theodosius,... En ALVAREZ CAMPOS 1981, vol. V, pp. 186-190). 
Emmanuel, quien es la vara del reino, engendrado y nacido de la raíz de Dios Padre, sin principio ni tiempo, reinando con este y con el Espíritu Santo sobre el cielo y la tierra. ${ }^{51}$ El jerarca antioqueno completa su exégesis destacando que, de todos modos, esa vara de Aarón significa también la germinación (engendramiento) y la concepción de Cristo sin semilla (semen) en las entrañas de la santa y siempre virgen María. ${ }^{52}$

El himnógrafo bizantino San Romano el Meloda (c. 490-c. 556) expresa poéticamente que la vara de Aarón, florecida sin ser irrigada, expresa lo mismo que lo profetizado por Isaías sobre el florecimiento de una vara o tallo en la raíz de Jesé: a su juicio, ambas varas, la de Aarón y la de Jesé, designan a María, quien, sin haber sido cultivada, germina un fruto, parido por ella, permaneciendo virgen después del parto. ${ }^{53}$

Poco después el Meloda prosigue indicando que las Escrituras, tras prefigurar a Cristo como el vaso del maná y la flor brotada de la raíz, designan también a su madre, María, como flor, vara y arca (de la Alianza), por ser una madre cuyo seno es abierto y gesta por obra del Espíritu Santo, aun cuando después de eso permanece cerrado, al extremo de poder decirse de ella: La Virgen parió, y después del parto permanece virgen. ${ }^{54}$

Hacia fines del siglo VI o inicios del VII el obispo hispanovisigodo San Isidoro de Sevilla (c. 556-636) suscribe la exégesis tradicional según la cual la vara seca de Aarón, que florece sin necesidad de humedad, es símbolo de la Virgen María, quien sin coito engendró al Verbo de Dios, Cristo, profetizado también por Isaías bajo la figura del florecimiento del tallo en la raíz de Jesé. ${ }^{55}$

Theotecnos, obispo de Livias en Palestina (s. VII), advierte contra la tentación de juzgar imposible el milagro producido en el cuerpo santísimo de la Madre de Dios, al permanecer virginal e incorrupto antes, durante y después del parto: según el teólogo palestino, en efecto, nos era conveniente la espiritual Arca de la Alianza (María), en

51 "Virgam autem Aaronis constat produxisse folia et amygdalas emisisse, in qua praesignificabatur nobis Emmanuel, qui est virga regni et quasi e radice Deo Patre ortus et natus est, sine principio et sine tempore et cum eo et cum Spiritu Sancto regnat in coelestia et in terrestria." (SEVERO DE ANTIOQUIA, Epistula ad Theodosium Alexandrinum. En ALVAREZ CAMPOS 1979, vol. IV/2, pp. 38-39).

52 "Significat autem virga etiam germinationem et conceptionem absque semine, ex Maria sancta semperque Virgine." (Ibid.).

53 "Nunc video virgam Aaronis floridam sine rigante, quam Amos filius Isaias mihi scripsit; " Ecce exiet virga », dixit, " ex Iesse, et ex radice flos ». Virga Aaronis et Iesse quae est? María sine cultu germinans fructum, quem mihi Virgo parit, et post partum iterum manet virgo." (ROMANO EL MELODA (Romanus Cantor), Hymnus 12, 4. En ALVAREZ CAMPOS 1979, vol. IV/2, pp. 129-130).

54 "Te, Iesu, monstrat Scripturas: alia manna et vas indicat, alia vero ex radice florem nuntiat. Et matrem tuam vocant florem, virgam, arcam, eam quae sinu portat per Spiritum aperta et post haec manet clausa; ut quisquis dicat : Virgo parit, et post partum iterum manet virgo." (Ibid.).

55 "Alii virgam hanc, quae sine humore florem protulit, Mariam Virginem putant, quae sine coitu edidit Verbum Dei; de qua scriptum est: « Exiet virga de radice Iesse et flos de radice eius ascendet. (Is. 11, 1) ». Id est Christus, qui futurae typum praeferens passionis, candido fidei lumine et passionis sanguine purpurabat corona martyrum, gratia continentium." (SAN ISIDORO DE SEVILLA, Quaestiones in Numeros, 15, 19. PL $83,348 \mathrm{C})$. 
la que se conservaba el vaso del maná y la vara floreciente de Aarón, la cual germinó un fruto sin defecto (Cristo). ${ }^{56}$

En la primera mitad del siglo VIII el prestigioso mariólogo San Juan Damasceno (675-749) alaba a María llamándola "vara, rama de una plantación divina, la única que parió entre todas las vírgenes", la cual, sin haber recibido simiente varonil (nullo semine suscepto), produjo como una flor al Hijo de Dios señor del universo. ${ }^{57}$

Por esas mismas fechas San Juan de Eubea (s. VIII) expresa ideas análogas, al afirmar que, así como la vara de Aarón, después de florecer, fue recolocada en el Arca de la Alianza recubierta de oro, así otra vara (María) florece sin necesitar simiente humana. ${ }^{58}$

En la transición del siglo X al XI San Fulberto, obispo de Chartres (c. 960-1028), sostiene que, de manera similar a la vara de Aarón fructificando sin raíz ni ningún otro recurso natural o artificial, la Virgen María sin intervención conyugal procreó un hijo, al cual se designa tanto con la flor como con el fruto: con la flor, por su hermosura; con el fruto, por su utilidad. ${ }^{59}$

Un par de generaciones más tarde el reformador y cardenal benedictino San Pedro Damián (c. 1007-1072), en un sermón con motivo de la Asunción, tras indicar que María es la vara de Aarón, con la que se reprimen los ímpetus de los demonios y mediante la que se operan todos los prodigios, insiste en que en la Virgen María se contiene la esperanza y el consuelo de los míseros con la vara y el báculo de la cruz. ${ }^{60}$

Casi una centuria después el reformador cisterciense San Bernardo (1090-1153), abad del monasterio de Claraval, reafirma con tenaz insistencia la identificación de la Virgen con la vara de Aarón. Por tal motivo, explotando el valor significante de esa metáfora de la vara reverdecida, floreciente y fructificada, el Claravalense, en la segunda de sus cuatro homilías en alabanza a la Virgen María, ${ }^{61}$ sostiene que Cristo es presignificado no solo por la flor, por el fruto y por las mismas hojas reverdecidas

56 "Et nemo diffidat tamquam sit impossibile miraculum quod sanctissimum corpus Deiparae fecit, ubi et virginale permansit et incorruptum. Decebat enim spiritualem arcam vas habentem mannae et virgam Aaronis floridam. Haec enim germinavit indeficientem fructum." (THEOTECNOS, Encomium Assumptionis sanctae Deiparae. En ALVAREZ CAMPOS 1979, vol. IV/2, p. 381).

57 "Ave, virga, divinae plantationis ramus, sola inter omnes virgines puerpera, quae, nullo semine suscepto, universorum Deum et hierarcham Filium, uti florem emissisti." (SAN JUAN DAMASCENO, Homilia II In Nativitatem B.V. Mariae, 7. PG 96, 690).

58 "Ecce et Aaronis virga, quae floruit, in arca undequaque auro circuntecta reponitur. Et ecce alia virga floret, non incise neque humano semine effabilis." (JUAN DE EUBEA (JOANNIS EUBAEENSIS), Sermo in Conceptionem Sanctae Deiparae, IV. PG 96, 1466).

59 "Nam sicut illa virga [la de Aarón] sine radice, sine quolibet naturae vel artis adminiculo fructificavit: ita Virgo Maria sine conjugali opere filium procreavit, filium sane flore designatum et fructu; flore, propter speciem, fructu, propter utilitatem." (SAN FULBERTO DE CHARTRES, Sermo IV. De Nativitate Beatissimae Mariae Virginis. PL 141, 321).

60 "Hanc est virga illa qua retunduntur ímpetus adversantium daemoniorum: virga Aaron, per quam fiunt signa et mirabilia. (...) In Virgine virga et baculo cruce miserorum spes et consolatio continetur." (SAN PEDRO DAMIAN, Sermo XL. In Assumptione Beatissimae Mariae Virginis (XV Aug.). PL 144, 721).

61 SAN BERNARDO, In laudibus Virginis Matris. En Obras completas de San Bernardo. Edición bilingüe Promovida por la Conferencia Regional Española de Abades Cistercienses, Vol. II. Tratados (2), Madrid, La Editorial Católica, Col. Biblioteca de Autores Cristianos, Madrid, 1984, pp. 600-679. 
de la vara de Aarón, ${ }^{62}$ sino también "por la misma vara" de Moisés, con cuyo golpe este separó las aguas del Mar Rojo para que su pueblo pasase y con la que hizo brotar agua de la roca para darle de beber. ${ }^{63}$ Sobre esa base argumental, el Doctor Melifluo sentencia:

No hay, pues, inconveniente alguno en que sea figurado Cristo en diversas cosas por diferentes causas; y que en la vara se entienda su potencia, en la flor su fragancia, en el fruto la dulzura de su sabor, en las hojas también su cuidadosa protección, con que no cesa de amparar bajo la sombra de sus alas a los pequeñuelos que se refugian a é1 huyendo de los carnales deseos y de los impíos que los persiguen. ${ }^{64}$

$\mathrm{Y}$ en otro sermón con motivo del Adviento, el abad de Claraval enuncia que la Virgen Madre de Dios es la vara o tallo, y Cristo su flor, "una flor cándida y rubicunda, elegida entre miles, una flor que desean ver los ángeles y cuyo olor resucita a los muertos", ${ }^{65}$ antes de proclamar con líricos efluvios:

¡Oh Virgen, vara sublime, a qué altura elevas tu sagrada copa! Hasta aquel que está sentado en el trono, hasta el Señor de la Majestad. Ni es de admirar esto, porque también llegan a lo profundo las raíces de tu humildad. ¡Oh verdaderamente planta celeste, la más preciosa, la más santa de todas! ¡Oh verdaderamente árbol de la vida, que sólo fue digno de llevar el fruto de la salvación! ${ }^{66}$

Medio siglo más tarde el diplomático y poeta francés Pierre de Blois (c. 1135-c. 1204), al evocar las delicias de la Virgen María, por ser la predilecta de Dios, preanunciada por los profetas, deseada por los patriarcas, saludada por el arcángel Gabriel y fecundada por el Espíritu Santo, testifica que lo prefigurado en la vara de Aarón, en el vellón de Gedeón, en la puerta de Ezequiel y en la zarza ardiente de Moisés es precisamente María: ${ }^{67}$ a juicio del autor, tales prefiguraciones se justifican por el hecho de que la madre de Cristo es "fecunda sin comercio carnal, preñada sin incómoda

62 "noveris in eadem Aaronica virga - quae non solum floruit, sed et fronduit, et fructum emisit-, non solum flore vel fructum, sed ipsis etiam frondibus eundem significari."(SAN BERNARDO, Homilia II in Laudibus Virginis Matris, 6. En Obras completas de San Bernardo, op. cit., p. 620).

63 "Noveris et apud Moysen nec fructu virgae, nec flore, sed ipsa virga demostrari, illa utique virga, qua feriente, aqua vel dividitur transituris, vel de petra excutitur bibituris." (Ibid.).

64 "Nullum autem inconveniens est, diversis rebus diversis ex causis Christum figurari, et in virga quidem potentiam, in flore vero fragantiam, in fructu autem saporis dulcedinem, in frondibus quoque sedulam eius intelligi protectionem qua videlicet parvulos ad se confugientes sub umbra alarum suarum protegere no desinit, sive $\mathrm{ab}$ aestu carnalium desideriorum, sive a facie impiorum, qui eos afflixerunt. " (Ibid.).

65 "Flos utique Virginis Filius, flos candidus et rubicundus, electus ex millibus, flos in quem prospicere desiderant angeli, flos ad cuius odorem reviviscum mortui". (SAN BERNARDO, In Adventu Domini. Sermo Secundus. En Obras completas de San Bernardo. Edición bilingüe promovida por la Conferencia Regional Española de Abades Cistercienses, vol. III. Sermones litúrgicos (1 ${ }^{\circ}$, Madrid, La Editorial Católica, Col. Biblioteca de Autores Cristianos, 1984, p. 74).

66 "O Virgo, virga sublimis, in quam sublime verticem sanctum erigis! Usque ad sedentem in throno, usque ad Dominum maiestatis. Neque id mirum, quoniam in altum mittis radices humilitatis. $\mathrm{O}$ vere coelestis planta, pretiosior cunctis, sanctior universis! O vere lignum vitae, quod solum fuit dignum portare fructum salutis!" (Ibid.).

67 "Delicias in Virgine voco, quia est a Domino praeelecta, et prophetis praenuntiata, a patriarchis optata, ab angelo salutata, a Spiritu sancto fecundata: quod in virga Aaron, quod in vellere Gedeonis, quod 
carga, alumbrante sin dolor en el parto", pues ella es la puerta de la vida, la primera de las vírgenes, y la amiga del eterno Dios. ${ }^{68}$

Por último, el teólogo y místico franciscano San Buenaventura (1218-1274), al explicar tres figuras bíblicas que metaforizan el nacimiento de Jesús en María -las dos primeras de las cuales son el esplendor que nace de la luz y el germen que nace de la vid-, sostiene que el tercer símil es la flor que brota de la rama. ${ }^{69}$ El lírico pensador destaca que, así como "la flor, al brotar de la rama, no la menoscaba, sino la mejora; no la resquebraja, sino la embellece", así también "Dios nace (...) de la Virgen fecundándola y embelleciéndola, sin violentar ni corromper su integridad virginal". ${ }^{70}$ Asumiendo la profecía de Isaías sobre el florecimiento de la vara en la raíz de Jesé, San Buenaventura insiste en que "por vara se entiende la Virgen, Madre de Dios; por flor, su divino Hijo; por salida de la vara, el nacimiento de la Virgen; por subida de la flor, el nacimiento del Salvador (...), y sobre la flor descansa el Espíritu Santo."”1

\section{Conclusiones}

Tras este amplio análisis de imágenes artísticas y textos doctrinales, creemos posible sintetizar algunos resultados esenciales de nuestra investigación:

Tal como lo ilustran las diez pinturas góticas españolas aquí analizadas, el ramo de lirios constituye un motivo frecuente, casi imprescindible, en las imágenes bajomedievales europeas de La Anunciación, en las que, por si fuera poco, asume un claro protagonismo, destacándose casi siempre con un tamaño notable en los primeros planos del cuadro.

Bajo la razonable conjetura de que tan frecuente y protagónica presencia del ramo de lirios en la iconografía de la Anunciación esconde algún simbolismo doctrinal de gran importancia, lucen insatisfactorias las interpretaciones que de esos lirios dan las monografías y diccionarios especializados en símbolos y motivos iconográficos. Parece, en efecto, poco oportuno en este tema mariano restringir-como hacen los au-

in Ezechielis porta, quod in rubo Moysi praesignata". (PIERRE DE BLOIS (PETRUS BLESENSIS), Sermo XXXIII, In Assumptione beatae Mariae. PL 207, 662-663).

68 "sine corruptione fecunda, sine gravamine gravida, sine dolore puerpera, quod ipsa est vitae janua, quod virginum primiceria, quod simul est Dei aeterni amica." (Ibid.).

69 SAN BUENAVENTURA, In Nativitate Domini, I, 1. En Obras de San Buenaventura. Edición bilingüe. Tomo II. Jesucristo (Edición dirigida, anotada y con introducciones por los padres León AMORÓS, Bernardo APERRIBAY y Miguel OROMÍ), Madrid, La Editorial Católica, Col. Biblioteca de Autores Cristianos, 1967, pp. 344-345).

70 "Oritur flos ex ramo vel ex arbore ita, quod nec ramum corrumpit, sed meliorat, nec aperit, sed decorat. Ita et Deus ex Virgine natus est non aperiendo, non corrumpendo, quia haec porta clausa erit in perpetuum; non aperietur, et vir non transibit per eam, ait Ezechiel, sed fecundando et decorando." (Ibid.)

71 "Ideo comparatur eius nativitas egressui floris; Isaiae undecimo: Egredietur virga de radice Iesse, et flos de radice eius ascendet, et requiescet super eum Spiritus Domini. Virgo Dei Genitrix virga est; flos, Filius eius; egressus virgae, nativitas Virginis; ascensus floris, nativitas Salvatoris; et hoc omnino de radice Iesse. Nam stirps Iesse virgam produxit virgaque florem, et super hunc florem requiescit Spiritus almus." (Ibid., p. $345)$. 
tores de esos libros- la interpretación del lirio a la pureza, la virginidad o la inocencia, ni siquiera en referencia exclusiva a la Virgen María.

El ramo de lirios en las Anunciaciones bajomedievales resulta, en cambio, claramente justificado sobre la base de una amplia y sólida tradición patrística y teológica, conforme a la cual muchos Padres de la Iglesia y teólogos medievales concuerdan en interpretar el florecimiento de la vara seca de Aarón según un doble simbolismo, simultáneamente cristológico y mariológico. A juicio de todos esos autores sacros, en efecto, ese prodigio veterotestamentario metaforiza al propio tiempo la virginal maternidad divina de María (a quien identifican como la vara seca de Aarón) y la concepción de Cristo, Hijo de Dios encarnado (a quien identifican como la flor y el fruto brotados en dicha vara seca).

Sobre esa base exegética, el hecho de que el ramo de lirio exhiba tan evidente protagonismo en casi todas las imágenes bajomedievales en estudio se justifica porque, al plasmar en formas artísticas el acontecimiento salvífico de la Anunciación, los programadores iconográficos de tales imágenes se inspiran en esa consolidada tradición patrística y teológica que interpreta el florecimiento de la vara seca de Aarón en función de esos dogmas cristológicos y mariológicos ya referidos. 